УДК 17.022.1:140.8

DOI:

Надія Ашиток, доктор філософських наук, професор кафедри загальної педагогіки та дошкільної освіти Дрогобииького державного педагогічного університету імені Івана Франка

\title{
НОВА ОСВІТНЯ РЕАЛЬНІСТЬ: ДИСТАНЦІЙНА ОСВІТА У ВИЩІЙ ШКОЛІ В УМОВАХ ПАНДЕМЇ̈
}

У статті зазначено, щзо одним із шляхів удосконалення освіти є застосування досягнень цицровізації. Цей прочес виявився актуальним в епоху пандемії. Цифрові технології здатні виконувати не лише соціальноекономічну, а й здоров'язбережувальну функиії. Незважаючи на неготовність освіти країни до переходу на дистанційне навчання, перша хвиля в період пандемії пройдена порівняно успішно, забезпечивши низький рівень захворюваності з коронавірусу у педагогів та учнів. Аналізуються переваги і недоліки дистанційного навчання. Докладно розглянуто можливість освітньої нерівності при иій формі навчання.

Ключові слова: нова освітня реальність; дистанційне навчання; вища школа; пандемія; ијировізація; цифрові технології.

Jim. 10.

Nadiya Ashytok, Doctor of Sciences (Philosophy), Professor of the General Pedagogy and Preschool Education Department Drohobych Ivan Franko State Pedagogical University

\section{NEW EDUCATIONAL REALITY: DISTANCE EDUCATION IN HIGHER SCHOOL IN PANDEMIC}

The article notes that changes in the technological, social and cultural spheres of society in our time have led to the fact that the traditional education system has partially ceased to meet the needs of individuals and society as a whole. One way to improve an education is to use digital technologies in education. This process proved relevant in the era of the pandemic, which created a new educational reality. In each of the countries of the world the educational reality in the conditions of a pandemic has got special features, characteristic as well as for Ukraine. The article considers the peculiarities of the functioning of distance education in this reality.

The aim of the article is to study distance learning as a manifestation of the new educational reality based on the introduction of digital technologies, analysis of the advantages and disadvantages of this form of learning.

It turned out that in a pandemic, digital technology can perform not only a socio-economic function, but also a health care function. Despite the apparent unpreparedness of the country's education system as a whole for the overall transition to distance learning, the first wave during the pandemic was relatively successful, as it provided a low incidence of coronavirus among teachers and students. The article analyzes the advantages and disadvantages of distance learning. The possibility of educational inequality is considered in detail.

At the end of the article it is noted that evidence of the manifestation of the new reality is the introduction of digital technologies in all spheres of society, including education. However, the importance of the transformation of education in this direction is special, because the effectiveness of changes in education largely determines the pace and quality of digitalization in other areas of the modern world.

Keywords: new educational reality; distance learning; high school; pandemic; digitalization; digital technologies.

П

остановка проблеми. Зміни в технологічній, соціальній та культурній сферах життєдіяльності суспільства в наші дні призвели до того, що традиційна система освіти частково перестала відповідати потребам конкретної людини та суспільства загалом. У відповідь на виклики сучасності держава змушена модернізувати цю систему. Одним із шляхів іiі удосконалення стає застосування в освіті досягнень цифровізації, яка є складовою глобального загально історичного процесу цифровізації суспільства. Цей процес набув особливої актуальності під час пандемії
COVID-19, що призвела до найбільшого за всю історію збою у функціонуванні систем освіти i торкнулася майже 1,6 мільярда учнів у більш ніж 190 країнах і на всіх континентах та зумовила необхідність активного використання сучасних інформаційних технологій і додаткових освітніх ресурсів в організації дистанційного онлайннавчання. Закриття шкіл та інших освітніх закладів вплинуло на організацію навчання 94 відсотків світового контингенту учнів, причому в країнах 3 низьким рівнем прибутку, а з рівнем прибутку нижче середнього цей показник становить 99 відсотків [7]. Як слушно зазначає генеральний 
директор компанії “Мобільна електронна освіта” доктор педагогічних наук, член-кореспондент РАО Олександр Кондаков, пандемія створила нову освітню реальність, у якій батькам, вчителям і особам, що навчаються, потрібно перебудовувати стосунки один з одним, розв'язувати завдання, у яких немає готових рішень, і зважати на роль цифрових технологій. Дослідник також додає, що поза всяким сумнівом, онлайн-навчання - це не просто довгостроковий тренд, а доконаний факт нашого життя із швидко зростаючою кількістю залучених користувачів [6]. У кожній з країн світу освітня реальність в умовах пандемії набула особливих рис, що характерно й для України. Специфіка функціонування дистанційної освіти в умовах зазначеної реальності вивчається у нашій статті.

Аналіз останніх досліджень і публікацій. Проблеми становлення нової освітньої реальності вивчали Д. Башкатова, Г. Гриффин, К. Черемісин $[3 ; 4 ; 10]$. О. Кондаков досліджував вплив пандемії на зазначений процес [6]. На особливостях організації дистанційного навчання в умовах поширення короновірусу зосереджували дослідницьку увагу Н. Ашиток, С. Бойко, К. Доня, О. Карагодіна, М. Карагодіна, О. Кондаков, О. Пожидаєва, О.Ташкінова та ін. С. Бойко, К. Доня i О. Ташкінова вивчали проблеми оцінювання якості організації дистанційного навчання студентів в умовах карантину [9, 77-82]. Предметом наукового пошуку М. Карагодіної, О. Карагодіної та О. Пожидаєвої було ставлення студентів до дистанційного навчання в період пандемії [5, 270-272]. Н. Ашиток студіювала інформаційно-комунікативний аспект розвитку сучасної вищої освіти $[1,128-131 ; 2,11-15]$. Незважаючи на численність праць, дистанційне навчання як прояв нової освітньої реальності недостатньо вивчене, а тому існує потреба в докладному його дослідженні.

Мета статті - вивчити дистанційне навчання як прояв нової освітньої реальності, що грунтується на цифрових технологіях, проаналізувати переваги і недоліки цієї форми навчання.

Виклад основного матеріалу дослідження. Як зазначали на глобальному онлайн-форумі EdHeroes "Ocвima в епоху пандемії: сім'я в фокусі”, пандемія створила нову освітню реальність на основі використання цифрових технологій [3]. Звісно, використання цифрових технологій зумовлене не лише потребою організації дистанційного навчання, а й змінами у соціальній і економічній сферах. Про це, зокрема, йдеться у дослідженні А. Черемісина, який зазначає, що в соціальній стратифікації в наш час все більшу роль віддають знання, а рівень освіти стає домінуючим фактором, який визначає приналежність індивіда до тієї чи тієї страти. Цей процес викликаний тим, що при застосуванні наукового знання в розвинених країнах витісняється з виробництва ручна, механізована праця як основний чинник ціноутворення. Найбільша додаткова вартість починає створюватися у сфері послуг, ІТ-технологій і маркетингу. В результаті найважливішим соціальним інститутом стають освіта і наука як основне джерело створення додаткового продукту для потреб економічних суб'єктів [10]. Цифрові технології, як слушно зазначає О. Кондаков, створили нове, мінливе соціокультурне середовище, в якому численні учасники взаємодіють за допомогою величезної кількості пристроїв, у тому числі 3 “розумним" функціоналом, технологій і сервісів, де "цифра" нових можливостей перетворилася на нове середовище існування людини. Цифрові технології, власне, і стали основою технологічної революції, iii драйвером, створивши безпрецедентні можливості для комфортної комунікації, взаємодії та спільної діяльності в зручний час, зручному місці, темпі та ін.; виникли безмежні можливості отримання будь-якої інформації і знання [6]. В умовах пандемії виявилося, що зазначені технології здатні виконувати не лише соціальноекономічну функцію, а й здоров'язбережувальну. Вже зараз можна зробити висновок, що, незважаючи на очевидну неготовність системи освіти країни до загального переходу на дистанційне навчання, перша хвиля в період пандемії пройдена порівняно успішно, забезпечивши низький рівень захворюваності 3 короновірусу у педагогів та учнів. Одночасно став очевидним низький рівень сформованості “цифрової грамотності”, ефективності використання цифрових технологій [6]. Крім наведеного, можна відзначити й інші підсумки дистанційного навчання: змінився статус особи, що навчається, оскільки при дистанційному навчанні виявилися актуальними такі компетенції особистості, як здатність до самонавчання, самоорганізації, саморефлексії; змінився статус педагога, який у нових умовах передусім має виступати у ролі консультанта, помічника, експерта, менеджера освітньої діяльності особи, що навчається; змінилося співвідношення між обсягами занять під керівництвом педагога та самостійноі роботи осіб, що навчаються, оскільки значний обсяг інформації студенти мають опановувати самотужки; виникла нагальна потреба в електронних підручниках, посібниках, навчальнометодичних рекомендаціях тощо; почали 
сприйматися як актуальні дешеві, надійні і зручні цифрові освітні платформи, що при дистанційному навчанні не лише виконують роль інструментів оптимізації освітнього процесу, а й формують принципово нове середовище розвитку особистості; виникла можливість для особи, що навчається, отримувати інформацію у зручний час незалежно від місця перебування; стало можливим використання сучасних технологій i мультимедійних засобів як педагогом, так і особами, що навчаються; цифрові навчальні матеріали доступні для всіх учасників освітнього процесу “тут і зараз”; навчальний матеріал може бути наочним, цікавим і доступним для розуміння і засвоєння особами, що навчаються; дистанційна форма створює умови для навчання за індивідуальними планами і програмами обдарованих осіб, людей з різними соціальними та психофізичними можливостями.

Для дистанційного навчання характерні й недоліки. До них належать: обмеженість спілкування (недостатність комунікативної взаємодії між педагогом і студентами, між особами, що навчаються; складність невербального спілкування при використанні електронних пристроїв, проблематичність емоційної залученості в комунікативний процес); складність у засвоєнні практичних навичок (навіть найсучасніші технології не замінять реальної практики); недостатній рівень контролю $з$ точки зору дисципліни; складність оцінювання осіб, що навчаються, внаслідок можливості використання ними джерел без посилання на авторів; проблематичність проведення виховної роботи, наприклад, з фізичного виховання.

До ризиків дистанційного навчання варто віднести можливість освітньої нерівності. При організації цієї форми навчання стало очевидним iï нове розуміння. Зокрема, О. Кондаков зазначає, що сьогодні це визначається насамперед наявністю комп'ютера і доступністю інтернету. Дистанційне навчання показало, що не у всіх сім'ях вдома є комп'ютери. У багатьох з них він один на кількох членів сім'ї. Не краще сім'ї забезпечуються інтернетом. Соціальноекономічний статус сімей і забезпеченість конкретної території широкосмуговим і доступним за ціною інтернетом в умовах переходу на онлайносвіту призвів до посилення освітньої нерівності за соціальними і територіальними можливостями [6]. М. Маніковська також вважає, що цифровізація суспільства посилює соціальну нерівність. Ця перспектива, вважає вона, пояснюється тим, що плоди цифровізації не можуть бути доступні всім однаковою мірою. Це наслідок не злої волі творців цифрових технологій, а реальна ситуація, обумовлена цілим спектром причин: економічних, освітніх, географічних, демографічних, етичних. Цифрова реальність вимагає адекватних їй знань, професійних умінь і навичок для взаємодії з реаліями цифрового середовища i, мабуть, не менш важливого чинника - наявності матеріальних засобів [8].

Висновки. Свідченням становлення цифрової реальності є впровадження цифрових технологій в усі сфери суспільства, в тому числі й освіти. Проте значення трансформації освіти у цьому напрямі особливого роду, адже ефективність змін у сфері освіти значною мірою визначає темпи і якість цифровізації інших сфер сучасного світу. Перспективи цифровізації всіх сторін людського життя вражають, проте існують ризики і негативні наслідки іï впровадження. Серед численних переваг впровадження цифрових технологій слід відзначити можливість функціонування на їх основі дистанційної форми навчання, яка в умовах пандемії сприяла збереженню здоров'я у педагогів та учнів. У наші дні дистанційне навчання пропонує великий спектр можливостей для отримання освіти, проте ця перспективна форма навчання далека від досконалості, існує низка проблем, які необхідно розв'язувати. Звісно, як слушно зазначав О. Кондаков, віртуальний клас (або аудиторія - Ашиток Н.) навряд чи замінить реальний у найближчі роки і навіть десятиліття. Проте важливо те, що педагоги вже пройшли колосальний шлях, по-новому оцінили свою роль в освітньому процесі, можливості нових технологій у повсякденній педагогічній практиці, оволоділи первинними навичками цифрової грамотності. Шкільний клас (або аудиторія для студентів - Ашиток Н.) змінився, і ми відчуваємо переваги змін, які поступово стали нормою нашого життя - новою нормальністю [6].

\section{ЛІТЕРАТУРА}

1. Ашиток Н.І. Інформаційно-комунікативний аспект розвитку сучасної вищої освіти в Україні. Вісник Національного авіаційного університету. 2020. №1 (31). C. 128-131.

2. Ашиток Н.І. Формування комунікативної компетентності студентської молоді у ВНЗ. Молодь і ринок. 2015. № 10 (129). С.11-15.

3. Башкатова Д. Форум EdHeroes: как действовать в новой образовательной реальности. URL: https://philanthropy.ru/novosti-organizatsij/2021/ $\underline{03 / 10 / 99082 /}$

4. Гриффин Патрик. “Навыки XXI века”: новая реальность в образовании. URL: https:// intalent.pro/article/navyki-xxi-veka-novaya-realnostv-obrazovanii.html\$ 
5. Карагодіна М. Карагодіна О., Пожидаєва О., Карагодіна М. Ставлення студентів до дистанційного навчання в період карантину. Інтернет-Освіта-Наука-2020. Матеріали міжнародної науково-практичної конференції (Вінниця, 26-29 травня 2020 р.). Вінниця, 2020. C. $270-272$.

6. Кондаков Александр. Уроки пандемии: новая реальность. URL: https://vogazeta.ru/articles/ 2020/6/26/Iniciativa_FGOS_40/13654uroki_pandemii_novaya_realnost

7. Концептуальная записка: Образование в эпоху COVID-19 и в последующий период. Август 2020 года. Організація Об'єднаних Націй. URL: https:// www.un.org/sites/un2.un.org/files/policy_brief__education_during_covid-19_and_beyond_russian.pdf

8. Маниковская М. А. Цифровизация образования: вызовы традиционным нормам и принципам морали. URL: https://cyberleninka.ru/ article/n/tsifrovizatsiya-obrazovaniya-vyzovytraditsionnym-normam-i-printsipam-morali.

9. Ташкінова О. А., Бойко Є. В., Доня К. В. Оцінка якості організації дистанційного навчання студентів ОП “Соціальна робота" у ДВНЗ “ПдТУ” під час пандемії Covid-19 (за матеріалами соціологічного дослідження). Reporter of the priazovskyi state technical university section: Socially-humanitarian sciences and public administration. 2020. Issue 6. P.77-82.

10. Черемисин А. Г. Конструирование новой социальной и образовательной реальности на основе Интернет-технологий : диссертация ... канд. социолог. н. Москва. 2010. 142 c. URL: http://www.dslib.net/socstruktura/konstruirovanie-novoj-socialnoj-i-obrazovatelnojrealnosti-na-osnove-internet.html

\section{REFERENCES}

1. Ashytok, N.I. (2020). Informatsiinokomunikatyvnyi aspekt rozvytku suchasnoi vyshchoi osvity v Ukraini [Information and communication aspect of the development of modern higher education in Ukraine]. Bulletin of the National Aviation University. No.1 (31). pp. 128-131. [in Ukrainian].

2. Ashytok, N.I. (2015). Formuvannia komunikatyvnoi kompetentnosti studentskoi molodi u VNZ [Formation of communicative competence of student youth in higher education]. Youth \& market. No. 10 (129). pp.11-15. [in Ukrainian].

3. Bashkatova, D. Forum EdHeroes: kak deystvovat $\mathrm{v}$ novoy obrazovatelnoy realnosti [EdHeroes Forum: How to Act in a New Educational Reality]. Available at: https://philanthropy.ru/novostiorganizatsij/2021/03/10/99082/ [in Russian].

4. Griffin Patrik "Navyiki XXI veka": novaya realnost v obrazovanii [21st Century Skills: A New
Reality in Education]. Available at: https://intalent.pro/ article/navyki-xxi-veka-novaya-realnost-vobrazovanii.html [in Russian].

5. Karahodina, M., Karahodina, O., Pozhydaieva, O. \& Karahodina, M. (2020). Stavlennia studentiv do dystantsiinoho navchannia $\mathrm{v}$ period karantynu. Internet-Osvita-Nauka-2020 [Attitudes of students to distance learning during quarantine. InternetEducation-Science-2020]. Materialy mizhnarodnoi naukovo-praktychnoi konferentsii (Vinnytsia, 26 29 travnia 2020 r.). - Proceedings of the International Scientific and Practical Conference Conference (Vinnytsia, 26-29 May 2020). (pp. 270 272). Vinnytsia. [Ukrainian].

6. Kondakov Aleksandr. Uroki pandemii: novaya realnost [Lessons from the pandemic: a new reality]. Available at: https://vogazeta.ru/articles/2020/6/26/ I n i c i t iv a F G O S 40/13654. uroki pandemii novaya realnost [in Russian].

7. Kontseptualnaya zapiska: Obrazovanie v epohu COVID-19 i v posleduyuschiy period. Avgust 2020 goda. OrganIzatsIya Ob'Ednanih NatsIy [Concept Note: Education in the COVID-19 era and beyond. August 2020. UN]. Available at: https://www.un.org/sites/un2.un.org/ files/policy brief _ _education_during_covid19 and beyond_russian.pdf [in Russian].

8. Manikovskaya, M. A. Tsifrovizatsiya obrazovaniya: vyizovyi traditsionnyim normam i printsipam morali [Digitalization of education: challenges to traditional norms and principles of morality]. Available at: https://cyberleninka.ru/article/ n/tsifrovizatsiya-obrazovaniya-vyzovy-traditsionnymnormam-i-printsipam-morali [in Russian].

9. Tashkinova, O. A., Boiko, Ye. V. \& Donia, K. V. (2020). Otsinka yakosti orhanizatsii dystantsiinoho navchannia studentiv OP "Sotsialna robota" u DVNZ "PDTU" pid chas pandemii Sovid-19 (za materialamy sotsiolohichnoho doslidzhennia) [Assessment of the quality of the organization of distance learning of students of OP "Social Work" in SHEI "PDTU" during the pandemic David-19 (according to sociological research]. Reporter of the priazovskyi state technical university section: Sociallyhumanitarian sciences and public administration. Issue 6. pp.77-82. [in Ukrainian].

10. Cheremisin, A. G. (2010). Konstruirovanie novoy sotsialnoy i obrazovatelnoy realnosti na osnove Internet-tehnologiy [Construction of a new social and educational reality based on Internet technologies]. Candidate's thesis. Moscow. 142 p. Available at: http://www.dslib.net/soc-struktura/konstruirovanienovoj-socialnoj-i-obrazovatelnoj-realnosti-na-osnoveinternet.html [in Russian].

Стаття надійшла до редакції 16.02.2021 